\title{
JOVENS DO SÉCULO XXI NA CULTURA \\ ANALÓGICA DO CINECLUBE ${ }^{1}$
}

\author{
THE YOUNG GENERATION OF THE XXI CENTURY AND THE FILM \\ CLUB ANALOG CULTURE
}

\section{LOS JÓVENES DEL SIGLO XXI EN LA CULTURA ANALÓGICA DEL CINECLUB}

\begin{abstract}
Mirna Juliana Santos Fonseca*
Quando a educação - tão velha quanto a humanidade mesma, ressecada e cheia de fendas - se encontra com as artes e se deixa alagar por elas, especialmente pela poética do cinema - jovem de pouco mais de cem anos -, renova sua fertilidade, impregnando-se de imagens e sons. Atravessada desse modo, ela pode se tornar um pouco mais misteriosa, restaura sensações, emoções, e algo da curiosidade de quem aprende e ensina. (FRESQUET, 2013, p. 19-20).
\end{abstract}

Resumo: A pesquisa tem como lócus dois cineclubes universitários que desde 2005 mantêm sessões contínuas para estudantes universitários. O artigo apresenta a história dos participantes desses cineclubes com o cinema, observando sua relação de consumo de filmes, desvendando como acontece a escolha pela cultura analógica do cineclube, uma vez que os jovens do século XXI fazem parte de uma cultura digital e virtual. Analisa, ainda, o que os estudantes destacam de relevante dessa experiência cineclubista em sua formação. Para tanto, foram entrevistados participantes desses cineclubes que consideram essa atuação relevante para sua formação.

Palavras-chave: Cineclubes universitários. Cinema. Formação. Cultura cineclubista.

Abstract: The research takes place in two universities film clubs that is in operation since 2005 and maintain continuous sessions to an audience consisting in mostly by college students. The paper presents the history of these film clubs participants with cinema, observing their films consumption, revealing how the choice of analogue film club culture is given, since the young generation of the XXI century are a part of a digi-

\footnotetext{
* Mestra em Educação pela universidade Federal do Estado do Rio de Janeiro; doutoranda em Educação pela Pontifícia Universidade Católica do Rio de Janeiro. Bolsista Capes Proex.
} 
tal culture. The article also analyses what these students portrait as relevant from these film clubs experiences in their education. To this end, were interviewed participants of these film clubs that considered their participation as relevant to their education.

Keywords: Universities film clubs. Cinema. Formation. Film club culture.

Resumen: La investigación tiene como locus dos cineclubes universitarios que desde 2005 mantienen sesiones continuadas a los estudiantes universitarios. El artículo presenta la historia de los participantes de esos cineclubes con el cine, observando su relación de consumo de películas, revelando como ocurre la elección por la cultura analógica del cineclube, puesto que los jóvenes del siglo XXI forman parte de una cultura digital y virtual. Además, se analisa qué los estudiantes destacan de relevante en esa experiencia con el cineclub en su formación. Para ello, fueron entrevistados participantes de esos cineclubes los cuales consideran esa actuación relevante a su formación.

Palabras clave: Cineclubes universitarios. Cine. Formación. Cultura de cineclube.

\section{INTRODUÇÃO}

O contexto cultural dos jovens da atualidade está estreitamente relacionado às mídias, destacando-se, entre elas, a narrativa cinematográfica, que pode ser considerada "[...] uma das mais importantes artes visuais da atualidade, com um imenso poder de atração e indiscutível potencial criativo" (DUARTE; ALEGRIA, 2008, p. 73), constituindo-se como um dos elementos do ambiente simbólico das novas gerações, possibilitando uma ampliação do contar e se afirmando como um cruzamento de práticas socioculturais diversas. Entre essas práticas, encontra-se o cineclube, que se constitui como espaço de alteridade ao englobar o filme, as pessoas e a própria cultura do cineclube.

Para Gusmão (2008), os cineclubes destacam-se quanto à sua contribuição na formação cinematográfica, pois propiciam a circulação de saberes e fazeres relacionados ao cinema, implementados por produtores e espectadores de diferentes gerações, "[...] tanto nos fluxos entre diferentes agentes e instituições no desenvolvimento de práticas como nas condições de transmissividade entre as gerações." (GUSMÃO, 2008, p. 3). Matela (2008, p. 53) conta que na década de 1960 “[...] (re)surgiram os cineclubes, a maioria nas universidades e ligados às entidades estudantis." Ao falar da história dos cineclubes, Amancio (2008) relembra da criação destes junto a escolas, paróquias e universidades. Sendo o cineclube um dos espaços em que se iniciaram as 
primeiras práticas que relacionaram o cinema à educação, é válido averiguar como esta prática vem atuando, hoje, na formação dos estudantes que frequentam cineclubes universitários. Conforme Macedo (2010, p. 47):

A ação cineclubista é central e essencial para a sociedade audiovisualizada. Se o audiovisual é central no processo político e social contemporâneo, a instituição audiovisual do público tem que ocupar posição central na organização desse público. [...] O cineclube deve estar presente em todas as comunidades e ter organização e meios para cuidar dessa intermediação do público e do audiovisual.

O autor ressalta a relevância desse espaço na formação social e humana, destacando a importância da existência de cineclubes nas "escolas de todos os níveis" (MACEDO, 2010). Essa é uma oportunidade que os participantes de cineclubes estão compartilhando, ao se encontrarem nas sessões: ver filmes (que geralmente estão fora do circuito comercial), discutir sobre o cinema e a partir daí eles conversam e aprendem sobre o que debatem ali, numa relação coletiva de alteridade. Assim, os cineclubes universitários se constituem numa oportunidade diferenciada de aprender para além do espaço institucionalizado da sala de aula, mesmo que dentro da universidade. De acordo com Duarte (2009, p. 68):

Precisamos tentar compreender, por exemplo, como se articulam, no processo de aprendizagem, os conhecimentos adquiridos na experiência com o cinema (televisão, Internet) e os conhecimentos transmitidos/produzidos, de forma sistemática, pelas atividades de natureza escolar e acadêmica. Precisamos saber de que maneira a linguagem escrita e a linguagem audiovisual combinam-se na produção de saberes e competências, para podermos fazer uso de ambas de forma mais eficiente e produtiva.

Desde seu nascimento, os cineclubes se constituem importantes espaços de formação. No início da história do cinema, há relatos de que nas reuniões que ocorriam nesses espaços se originaram termos usados na cinematografia até os dias atuais; nos cineclubes também se formaram grandes nomes da história dessa cultura. No Brasil, por exemplo, vários cineastas e críticos de cinema recorriam a essas reuniões e debates, quando ainda não existiam faculdades voltadas para o cinema.

É interessante observar que na sua história, desde seu surgimento na Europa até sua incursão no Brasil, os cineclubes apoiaram manifestações populares e de comunidades locais. Durante o regime militar, por exemplo, o movimento cineclubista brasileiro girava em torno de causas políticas, formando uma geração (MATELA, 2008). 
Neste artigo, buscamos analisar as relações estabelecidas entre os estudantes e os cineclubes universitários - CinePUC e Cinerama Eco -, partindo da história dos jovens pesquisados com o cinema, passando pelas relações de consumo estabelecidas por eles com os filmes. Para tanto, analisamos como jovens do século XXI - imersos na cultura digital/virtual - se relacionam com a cultura do cineclube, finalizando com observações sobre como eles compreendem a formação que têm nesses espaços.

Acreditamos, assim como Duarte (2009), que ver filmes é uma prática social tão importante, do ponto de vista de formação cultural e educacional das pessoas, quanto a leitura de obras literárias, filosóficas, sociológicas e tantas mais. Apresentamos, a seguir, os cineclubes pesquisados.

\section{CINEPUC E CINERAMA ECO}

A pesquisa aqui apresentada teve início em agosto de 2011, quando realizamos uma busca na internet por cineclubes que funcionassem em universidades e encontramos nas universidades do Rio de Janeiro e região metropolitana 18 cineclubes que funcionavam integrados a disciplinas, grupos de pesquisa, ou mesmo como projetos de extensão, dentro de alguma universidade. Após contato com os organizadores e análise do questionário respondido por eles sobre questões referentes ao funcionamento, atividades e o público que frequentavam esses espaços, escolhemos o CinePUC e o Cinerama Eco para a pesquisa, pois o público de ambos é constituído, em sua maioria, por universitários, e apresentam sessões constantes.

Fundado em 2005 pelos estudantes da recém-criada (na época) Habilitação em Cinema do curso de Comunicação, o CinePUC é organizado por Thiago Ortman e Caíque Melo $^{2}$ e tem como objetivo possibilitar o acesso a filmes e diretores aos estudantes de cinema desta universidade, ou qualquer pessoa que tenha interesse em cinema. As sessões são divulgadas pelo Facebook ${ }^{3}$ e acontecem na sala K-102 da Pontifícia Universidade Católica (PUC) todas as terças-feiras letivas, às 19h, com público médio de 15 pessoas.

O CinePUC não tem vínculo formal com nenhuma disciplina, projeto de extensão, curso ou departamento da universidade. Quando enviamos questionário com perguntas sobre funcionamento e organização deste cineclube, Thiago Ortman respondeu: "Eu particularmente acredito que aprendi muito mais (em termos teóricos) sobre cinema no cineclube do que no curso." Nesse cineclube, os debates não têm um direcionamento e todas as colocações trazidas pelos participantes partem do que 
é visto nos filmes, como questões políticas, culturais, sociais, além de comentários sobre as escolhas estéticas e artísticas do diretor, entre outras.

O Cinerama Eco funciona desde 2005 e tem por objetivo promover a cultura cinematográfica e pensar criticamente o cinema, principalmente o cinema brasileiro. Trata-se de um projeto de extensão que chegou à configuração de disciplina complementar por demanda dos estudantes de Rádio e TV (uma das habilitações do curso de Comunicação da Universidade Federal do Rio de Janeiro - UFRJ), por conta de uma lacuna existente neste curso no que concerne à exibição de filmes e de pontos de referência em relação ao debate sobre cinema. As sessões desse cineclube acontecem todas as quartas-feiras do semestre letivo às $19 \mathrm{~h}$ no Auditório do Centro de Produção Multimídia (CPM) da UFRJ e a frequência do público fica em torno de 35 pessoas por sessão. Quanto à sua organização, o cineclube conta com três bolsistas de extensão e estudantes que atuam voluntariamente como colaboradores na organização das sessões.

As sessões consistem em filmes seguidos de debate, mediados por algum professor que tenha pesquisa sobre os temas tratados nos filmes, ou mesmo o próprio diretor do filme, ou, ainda, alguém ligado à produção, como roteirista, ator ou produtor. Quando não há convidados para encaminhar as conversas sobre o filme, os estudantes fazem suas discussões a partir de suas próprias impressões, estabelecendo ali um debate não menos interessado do que quando há um mediador. A divulgação das sessões é feita pelo Facebook ${ }^{4}$.

Os cineclubes pesquisados conseguem mudar um pouco a ordem posta dentro da universidade, fazendo, de certa forma, os estudantes pararem, pensarem, ouvirem, enfim, deixarem-se atravessar pela experiência (LARROSA BONDÍA, 2002) com o cinema, assistindo a filmes e discutindo sobre eles.

A história do cineclubismo no Brasil mostra incursões de suas atividades dentro da universidade, ou mesmo, partindo desta. Atualmente, as atividades promovidas pelos cineclubes universitários não são as mesmas da época da ditadura - momento de forte atuação do cineclubismo junto aos jovens (MATELA, 2008) -, pois os tempos e convicções mudaram. Porém, acreditamos que esta continua a ser uma atividade subversiva no que concerne ao consumo de filmes e à maneira de relacionar-se com o cinema nesses espaços, nos dias de hoje.

Após 15 visitas aos cineclubes pesquisados, registrando nossas impressões em diários de campo, realizamos entrevistas semiestruturadas com seis jovens participantes e/ou organizadores dos cineclubes escolhidos. Por meio desse instrumento da pesquisa qualitativa, buscamos compreender o modo como os estudantes se relacionam com os filmes, com o cinema e com os cineclubes. Destacamos, a seguir, 
os aspectos relevantes dessas relações e, por fim, como esses jovens compreendem a formação vivenciada nesses espaços.

\title{
3 CONSUMO DE CINEMA
}

O que os estudantes contam sobre sua relação com o cinema é válido para conhecermos que contato foi estabelecido com os filmes para, em seguida, compreendermos como ocorreu o interesse pelas atividades do cineclube.

Os entrevistados são unânimes sobre sua aproximação com o cinema - e aqui estamos tomando o termo de forma abrangente, designando a arte, o espaço e também os filmes, independente do suporte em que são exibidos - por meio das produções de grande circulação na época de sua infância, como os filmes da Disney. Eles contam experiências de idas a salas de cinema quando crianças junto com pessoas da família:

\begin{abstract}
Ah, desde pequena, eu fui muito acostumada a ver filmes e tal, e aí a gente tinha o hábito de ir ao cinema até como um programa de família quando a gente era mais novo, eu tenho dois irmãos também. Ah, não sei, acho que foi meio essa cultura mesmo de sempre ir ao cinema; quando antigamente era mais barato era mais fácil, também, de assistir muitos filmes. (Carolina).

Eu não me lembro qual foi o filme, o primeiro filme que eu vi, nem os primeiros filmes que eu vi, mas eu lembro que eu já ia muito cedo ao cinema, minha mãe me levava e eu gostava muito de assistir filmes. [...] Na minha infância, eu assistia muito filme, muito filme, assim na Sessão da Tarde - essa relação que acho que a minha geração tem muito com filme, que é com a televisão - e, eventualmente, ia no cinema. (Caíque) (informações verbais).
\end{abstract}

A maior parte dos entrevistados assistia a filmes alugados, em casa, na TV, pois na infância deles (década de 1990) foi forte a influência desse tipo de comércio de filmes, com o advento dos videocassetes, que acarretou na proliferação de locadoras de fitas em VHS, substituídas pelos DVDs a partir de 1995:

No começo foram os filmes que me impuseram, eu assistia esses filmes, quando era moleque mesmo, da Disney, tudo mais, assistia televisão sempre depois do colégio, sempre assistia a filmes. Mas eu acho que um passo a mais que eu dei foi quando abriu uma locadora perto lá de casa - isso eu tinha uns 12 ou 13 anos. (Diego).

[...] desde criança eu sempre vi muitos filmes porque meu pai tinha duas locadoras - uma em Jacarepaguá, outra aqui em Laranjeiras - então, desde criança eu sempre vi muito filme, mas 
sempre cinema megacomercial, filmes da Disney, enfim, cinemão em geral. (Clarissa) (informações verbais).

Nessas falas, conseguimos perceber que, na infância, os sujeitos tiveram maior contato com cinema assistindo a filmes veiculados pelas redes de TV, alugando fitas e DVDs em locadoras, ou no "cinema mesmo". A tônica dos discursos é que os filmes da Disney foram seus iniciantes no cinema.

Os sujeitos revelam como tem sido atualmente seu consumo de filmes, destacando entre eles a internet, os festivais e mostras, além dos cineclubes. Todos são unânimes e afirmam que não vão há tempos a salas de cinema, que eles chamam de "cinema mesmo". Eles alegam que o valor do ingresso é muito caro (embora paguem meia-entrada), preferem os festivais, não se interessam pelo que é exibido no circuito comercial, ou preferem ter acesso aos filmes pela internet, como mostram as falas a seguir:

[...] tenho ido acho que uma vez por mês, assim, então, eu não posso dizer que a minha relação atual seria tão grande por diversas questões de tempo mesmo. [...] E eu acho que isso tem diversos fatores aí que influenciaram isso: a própria internet, o fato de você poder consumir tudo ali [...]. A minha relação com cinema, assim, tipo, "o espaço cinema" é muito importante, apesar de eu estar num momento afastado dele, assim. [...] No Festival do Rio, não no último ano, mas assim em outros anos, eu parava para ir ao cinema. Eu pegava aquele momento para ficar, sei lá, um mês, 15 dias, que é o tempo do Festival do Rio - indo, vendo filmes, 3 filmes por dia, às vezes, sabe? [...] $\mathrm{O}$ negócio é: muitas vezes, pra mim, sei lá, eu tenho desinteresse de alguns filmes que estão por aí, circulando. E aí eu acho que é isso que eu falei da internet. Eu acho que a internet oferece esse caminho, entendeu? Tipo, é quase um cardápio que você pode ali chegar e: "Ah, não, na verdade eu quero ver esse daqui", entendeu? (Thiago).

Ir ao cinema mesmo, Arteplex, cinema pago, eu vou bem pouco, na verdade. Devia ir mais, mas vou pouco, assim uma vez por mês. Eu vou mais em mostra. [...] Mas aí eu acabo assim, não escolho muito o filme que vou ver, eu vou ver o que tá rolando, assim, até porque é de graça. Porque cinema é caro até meia-entrada. [...] Hoje em dia, eu baixo tudo da internet, do Making off, do site, não alugo não. (Clarissa) (informações verbais).

Há quase uma unanimidade quando o assunto é o cinema comercial: eles preferem não pagar, pois os filmes não interessam e, quando querem ver algo, baixam na internet. As mostras e festivais têm uma peculiaridade importante para estudantes de cinema e comunicação: elas trazem filmes ainda inéditos ou de difícil acesso. Em mostras de diretores específicos, é possível assistir a filmes jamais lançados no país, 
sem falar da oportunidade de vê-los projetados em tela grande com som e imagem "dignos" do filme. As mostras trazem um panorama da obra de um cineasta, ator, ou ainda de um tema. Já os festivais trazem títulos inéditos e que possivelmente não entrarão em cartaz no circuito comercial. Além desse caráter diferenciado das mostras e festivais, a questão do preço é algo bem relevante para esses universitários.

O consumo de filmes desses sujeitos está atrelado ao valor dos ingressos, tanto quanto a importância de conhecer cinematografias históricas, diferenciadas e inéditas, e representativas da obra de um diretor. A escolha é pela obra, pelo cineasta, sempre observando se vai custar pouco ou quase nada. Isso se justifica pelo fato de terem acesso gratuito a essas obras por meio da internet. Em relação aos festivais e mostras, o que interessa é a oportunidade de assistir no formato original em que foi filmado - geralmente em película, numa tela gigante, com som e imagem de alta qualidade - um filme que já deve constar na pasta de filmes baixados. O consumo de filmes nesses eventos não está atrelado à questão de ter mais um filme no repertório, mas sim ao fato de tê-lo assistido no suporte para o qual ele foi concebido: a telona do cinema.

O consumo é um conceito teorizado por estudiosos de várias áreas, desde a psicologia e a antropologia, passando pela política e a economia, até a comunicação e ultimamente tem estado em foco nas pesquisas da área de educação. García Canclini (2010) busca um conceito de consumo baseado nas relações de recepção e comunicação de bens simbólicos. Portanto, seu conceito pode nos servir, uma vez que tratamos da recepção de filmes, da escolha de espaços para relacionar-se com o cinema como arte, como produção, na construção de uma cultura que é tecida na relação com o outro, com o cinema e com o próprio cineclube.

Para construir um conceito de consumo, uma vez que não existe uma teoria sociocultural sobre isso, García Canclini (2010) faz um levantamento de várias definições referentes a esse tema. A primeira delas percebe o consumo como uso e apropriação de produtos que se estabelecem por meio dos processos socioculturais, sendo este compreendido pela sua "racionalidade econômica" (GARCÍA CANCLINI, 2010, p. 61); numa segunda definição, conforme compreendem várias correntes, o consumo é encarado como "um momento do ciclo de produção e reprodução social, é o momento em que se completa o processo iniciado com a geração de produtos, em que se realiza a expansão do capital e se reproduz a força de trabalho" (GARCÍA CANCLINI, 2010, p. 61); a terceira definição engloba o consumo "como lugar de diferenciação e distinção entre as classes e os grupos" (GARCÍA CANCLINI, 2010, p. 62) - aqui estão os teóricos que abordam as questões de distinção simbólica entre classes ou entre grupos de uma mesma classe, como Pierre Bourdieu. "A lógica que rege a apropriação dos 
bens como objetos de distinção não é a da satisfação das necessidades, mas sim a da escassez desses bens e da impossibilidade de que outros os possuam." (GARCÍA CANCLINI, 2010, p. 63).

García Canclini (2010, p. 70-71) chega a um conceito de consumo, articulando-o "com um exercício refletido da cidadania":

[...] o consumo é visto não como a mera possessão individual de objetos isolados, mas como a apropriação coletiva, em relações de solidariedade e distinção com os outros, de bens que proporcionam satisfações biológicas e simbólicas que servem para enviar e receber mensagens. [...] Nós, seres humanos, intercambiamos objetos para satisfazer necessidades que fixamos culturalmente, para integrarmo-nos com os outros e para nos distinguirmos de longe, para realizar desejos e para pensar nossa situação no mundo, para controlar o fluxo errático dos desejos e dar-lhes constância ou segurança em instituições e rituais.

Os sujeitos desta pesquisa consomem cinema também por meio da "apropriação coletiva, em relações de solidariedade", promovida pelo cineclube. Mesmo tendo esses filmes em casa ou na locadora, eles se permitem uma nova experiência com o filme, por meio do debate que acontece nesse espaço, estabelecendo uma relação com os filmes que assistem/consomem, por meio de um processo diferente. Eles não se interessam pelo cinema pago, preferem aqueles espaços gratuitos ou baratos, onde geralmente haverá um intercâmbio de experiências relacionadas ao filme e ao cinema. Essa constatação nos indica, então, o motivo de terem tanto interesse pelo cineclube:

É, questões que o filme traz, questões estéticas. Aqui [Cinerama] a gente acaba falando um pouco mais de produção, umas coisas mais práticas. Ainda mais quando vem o diretor e a gente tem oportunidade de conversar com o diretor, a gente pergunta questão de produção, coisa de câmera, fotografia, umas coisas assim mais práticas, não técnicas, técnicas também. (Clarissa). Se todo cinema, depois do filme que fosse exibido, tivesse uma discussão, certamente as coisas ganhariam mais. Cara, o filme ganha muito! É impressionante. [...] Eu lembro muito de um filme que a gente passou do Murnau, "O último dos homens", um filme do expressionismo alemão que não tinha muito diálogo, era um filme teatral e que a gente chamou o Alexandre Costa que é um filósofo e veio com toda uma bagagem filosófica sobre o que o filme tava querendo [...] E não foi uma linguagem complexa. Eu acho que ele trouxe uma dimensão pro filme muito maior do que a gente esperava. (Diego) (informações verbais).

A relação de consumo que os jovens entrevistados na pesquisa estabelecem com o cinema pode ser resumida da seguinte forma: a maioria baixa filmes para assis- 
tir em casa na TV, ou mesmo no computador; um deles afirmou que aluga filmes para assistir na TV; a maioria não vai a salas de cinema, mas há alguns que acompanham as novidades do circuito comercial com alguma regularidade; preferem assistir aos filmes em mostra; todos eles frequentam pelo menos um cineclube.

\section{CULTURA ANALÓGICA DO CINECLUBE}

Em pleno século XXI, momento de proliferação de diversas mídias e suportes digitais, num tempo em que nos encontramos face a face por meio de programas de computadores, tablets, ou celulares, por que ir ao cineclube? Por que esses jovens se relacionam com/em um espaço onde geralmente assistem a filmes antigos, com apenas uma opção, em contraponto ao que oferecem os grandes complexos de cinema dos shoppings centers, por exemplo? Esses sujeitos de que falamos, estão conectados dia e noite à internet e podem assistir de graça aos filmes que quiserem, baixando em sites especializados, tanto os títulos antigos e difíceis de conseguir quanto aqueles que ainda nem estrearam nos cinemas nacionais. Eles vivem em uma cultura digital e virtual, porém escolheram se relacionar com/consumir os filmes de outra maneira, num espaço e tempo que exige a troca com outros, o parar para ver e debater ali, naquela hora e com aqueles interlocutores.

Consideramos a prática social cineclubista analógica ${ }^{5}$ porque nesse espaço é preciso estar desconectado do mundo virtual/digital e é imprescindível estar presente para participar das discussões, numa relação coletiva de alteridade. Os jovens que frequentam os cineclubes pesquisados vão justamente contra a ordem posta em relação ao domínio sobre os produtos a que têm acesso, nesse caso, os audiovisuais. Esses sujeitos escolheram ver filmes no modo analógico - e aqui não nos referimos à projeção do filme, mas ao tipo de recepção, por meio de uma cultura que tem quase a mesma idade que o cinema: a cultura cineclubista.

Ao realizarmos a entrevista, solicitamos que cada um dos jovens preenchesse um quadro com questões a respeito da frequência com que realizam algumas atividades ou frequentam determinados lugares. As respostas nos mostraram o perfil sociocultural do grupo pesquisado, composto por seis jovens - como já destacamos, deixando clara a frequência com que os entrevistados consomem produtos audiovisuais e culturais, como resumimos no quadro a seguir: 
Quadro 1 - Perfil de consumo sociocultural dos entrevistados

\begin{tabular}{|l|l|l|l|l|l|l|}
\hline & Nunca & $\begin{array}{l}4 \text { vezes } \\
\text { por ano }\end{array}$ & $\begin{array}{l}1 \text { vez } \\
\text { por mês }\end{array}$ & $\begin{array}{l}\text { Até 3 } \\
\text { vezes } \\
\text { por mês }\end{array}$ & $\begin{array}{l}\text { vezes } \\
\text { por } \\
\text { emana }\end{array}$ & $\begin{array}{l}\text { Todos } \\
\text { os dias }\end{array}$ \\
\hline Assistir a televisão & & & 2 & 2 & 1 & 1 \\
\hline Ouvir música & & & & & 1 & 5 \\
\hline Ouvir rádio & & 1 & 3 & & 2 & \\
\hline Ir ao teatro & 1 & 1 & 3 & 1 & & \\
\hline Ir a concertos ou balés & 2 & 4 & & & & \\
\hline Ir a shows & & 3 & 2 & 1 & & \\
\hline Ir ao cinema & & 1 & 2 & 2 & 1 & \\
\hline Assistir a competições esportivas & 3 & 2 & & & 1 & \\
\hline Utilizar a internet & & & & & & 6 \\
\hline Ir à biblioteca & 1 & 2 & 1 & 1 & 1 & \\
\hline $\begin{array}{l}\text { Visitar exposições, museus, centros } \\
\text { culturais }\end{array}$ & & 1 & 1 & 4 & & \\
\hline
\end{tabular}

Fonte: o autor.

É interessante observar como estudantes de cinema não vão ao "cinema mesmo", com tanta regularidade como imaginamos. Da mesma forma, esses sujeitos não assistem TV com grande frequência. Porém, todos os dias eles acessam a internet e ouvem música, mas não no rádio, já que muitos responderam não ouvir rádio com frequência. Assim, nos deparamos com o paradoxo de alunos do curso da UFRJ, cuja habilitação em Comunicação é denominada "Rádio e TV", que não fazem uso contínuo dessas mídias. Outra informação instigante que esse quadro traz é que esses sujeitos não estão interessados em competições esportivas, pois três deles nunca assistem a competições esportivas.

O quadro mostra também o quanto esses jovens estão ligados ao mundo digital e virtual, bem próprio da sociedade de que fazem parte. Com a frequência que temos a teatros e concertos, podemos dizer que esses não são espaços de maioria jovem, embora estes se façam presentes. As bibliotecas têm se tornado lugares carentes de jovens e o quadro mostra que esse também não é um interesse dos sujeitos aqui pesquisados, pois um deles relatou, inclusive, nunca ter estado numa biblioteca, mesmo sendo um estudante universitário.

Com os seis respondendo que acessam a internet todos os dias, fica claro o quão virtual e digital é esse público. Mas como um público digital, o que instiga esses jovens a participarem de um cineclube, espaço que carrega em si uma relação analógica, em que há espaço e hora certos, semanais, para encontro, é necessário estar presente pessoalmente para participar e, além disso, geralmente não se assiste obra mais nova do cineasta mais badalado do momento? Essa escolha está no debate. Os jovens 
revelaram o quanto o debate se mostra importante para sua frequência ao cineclube. Para eles, discutir o filme é muito instigante e os faz perceber aquela obra de outra maneira, dando conta de aspectos para os quais não haviam atentado ainda. Macedo (2010) define o cineclube como um espaço que vai além da mera exibição de filmes, caracterizando-o como um lugar de "apropriação do audiovisual em todas as suas dimensões." (MACEDO, 2010, p. 48-49). Entre essas dimensões, o autor considera o debate "como instrumento convivial de compreensão e formação, através de compartilhamento das experiências do público.” (MACEDO, 2010, p. 49). O público do cineclube busca a troca coletiva numa relação múltipla de alteridade - com os filmes, com os colegas e com a cultura do cineclube. Ainda conforme Macedo (2010, p. 49):

O "debate" - inventivo, informal - propicia e favorece a troca de experiências pessoais e comunitárias com vistas ao conhecimento e construção coletiva da visão de mundo, dos interesses e identidade do público. Assim, como das subjetividades individuais dos participantes.

Essa atividade que caracteriza um cineclube é o grande motivador para que esses estudantes continuem frequentando o espaço não digital, não virtual do cineclube. De acordo com uma entrevistada:

Eu acho que debate é sempre bom porque, por exemplo, aqui no Cinerama, a gente viu o filme do Buster Keaton, "The camera man", que em português é "O homem das novidades". O debate depois com o Alexandre, ele praticamente deu uma aula sobre a compreensão do filme [...] Porque quando você vê o filme, às vezes, você não consegue absorver tudo o que o filme traz, as questões que o filme traz. E quando você conversa sobre isso depois, parece que é muito mais esclarecedor, sabe? E também o confronto de ideias, isso enriquece muito um filme. (Clarissa) (informação verbal).

O debate é visto como "enriquecedor" e, portanto, modifica a maneira de compreender um filme. Baecque (2010, p. 32) destaca a importância de se conversar sobre o que se assiste no cinema:

Pois o cinema exige que se fale dele. As palavras que o nomeiam, os relatos que o narram, as discussões que o fazem reviver - tudo isso modela sua existência real. A tela de sua projeção, primeira e única que conta, é mental: ela ocupa a cabeça dos que assistem aos filmes para, em seguida, sonhar com eles, partilhar suas emoções, evocar sua memória, praticar sua discussão, sua escrita. 
Aqui nos deparamos com um hibridismo: jovens do século XXI (conectados diuturnamente na internet e que mantêm relacionamentos em redes sociais, com acesso aos filmes que quiserem assistir, pois baixam na internet) escolhem ver e debater filmes em modo presencial, numa relação de alteridade coletiva.

Eu acho que debater é muito importante, não só a linguagem como o conteúdo, porque você vê coisas que você não tinha visto antes, também, sabe? A partir do olhar do outro, você começa [...] "Puxa, eu não reparei nisso". [...] Você vai também criando, elaborando melhor o seu próprio pensamento, os seus argumentos que você vai tentando entender porque que você pensa diferente daquela pessoa. (Carolina) (informação verbal).

Como explica Caíque, houve filmes que ele somente passou a gostar depois que participou de um debate sobre ele:

$\mathrm{Eu}$ acho que sempre engrandece de alguma forma, de algum jeito a sua cultura, o seu conhecimento. [...] os debates são fundamentais. Tem vários filmes que eu gostei muito mais por causa do debate, ou eu só gostei por causa do debate, e aí me fez ter uma outra visão sobre aquele filme que eu não tinha. [...] $\mathrm{Eu}$ acho que as duas coisas são importantes. Mas uma coisa não elimina a outra, você pode só ver o filme e ficar pra você. E isso já é muito importante. (informação verbal).

A partir do debate são promovidos encontros, embates de opiniões, descobertas sobre o filme em diversos âmbitos, como alguma curiosidade de gravação revelada pelo diretor, ou certos truques de maquiagem, montagem ou edição, e até mesmo algumas mudanças de roteiro no meio do processo.

O que é legal do cinema - e também mais ou menos de qualquer obra de arte, de qualquer tipo de arte -, o cinema, o filme [...] Quando você assiste, termina de assistir o filme, ele só aconteceu pela metade. A outra metade é você digerindo esse filme. Então, o simples fato de uma pessoa falar uma coisa sobre o filme, ela certamente vai falar coisas que eu não percebi, e eu vou pensar em coisas que ela não percebeu. Então, essa troca é a segunda metade do filme. Por isso que eu acho legal, entendeu? Por isso que eu acho que eu não consigo ir a cinema e depois voltar pra casa. Eu tenho que ir com alguém, vou ao cinema, assisto ao filme, vou tomar uma cerveja, porque eu não consigo. Eu não consigo não comentar o que eu vi, entendeu? Isso é uma necessidade fisiológica (risos). (Nicholas) (informação verbal).

Nicholas deixa claro que o debate, a conversa sobre o filme, constitui-se "a segunda metade" da obra. "Ir ao cinema, assistir aos filmes, isso não se compreende sem esse desejo de prolongar sua experiência pela fala, pela conversa, pela escrita. 
Cada uma dessas rememorações confere verdadeiro valor ao filme." (BAECQUE, 2010, p. 33). Nesse caso, debater chega a ser uma necessidade construída por esse jovem que não consegue assistir a um filme sem conversar sobre ele com outra pessoa. Algo muito parecido foi relatado por Caíque, ao revelar sua busca em discutir filmes, ao entrar na faculdade de cinema:

Então, assim, eu já tinha essa vontade de ver filmes em conjunto e conversar sobre eles, depois, e o CinePUC foi essa possibilidade. E com o tempo a gente vai entrando e tal, fica um pouco envergonhado no princípio, mas depois você vai se abrindo e vai conversando, e ali era o espaço ideal pra isso, quando na sala de aula a gente não tinha esse espaço. (Caíque) (informação verbal).

Essa fala de Caíque mostra que numa faculdade de cinema, no espaço de educação formal, não era possível conversar sobre filmes - algo que ele só conseguiu no cineclube, por meio dos debates.

No depoimento a seguir, Diego considera os debates como uma aprendizagem diferente daquela estabelecida em sala de aula. Nesse momento essencial da atividade cineclubista, há uma relação horizontal, uma troca, e talvez por isso seja algo tão interessante para esses sujeitos. Essa curiosidade de saber como foi feito, de entender as escolhas dos cineastas, de interpretar aquilo que o filme quer dizer é que ainda move esses jovens do século XXI ao relacionarem-se com a cultura analógica do cineclube.

E muitas vezes o cara é tão bom que a gente fica só hipnotizado
vendo o discurso do cara e a gente vai, e às vezes tem menos
perguntas, mais escuta, às vezes não. Mas eu acho que funciona
muito porque é o aluno se colocar não exatamente como aluno,
ali, mas como um [...] Curioso, sabe? Não tem esse intermé-
dio tão forte entre o professor e o aluno. Na aula do Cinerama
não tem esse paradigma tão forte. Então fica uma coisa mais à
vontade, muitas vezes surgem questões que talvez não sairiam
numa sala de aula. E eu vejo muita gente tomando voz, é muito
importante isso, do aluno chegar e falar sua opinião com mais
força, tipo, não precisar de uma relação de troca tão vertical, ali
é mais horizontal. (Diego) (informaça verbal).

Nessa relação coletiva de alteridade que os jovens estabelecem com a cultura do cineclube, eles diferenciam-se dentro de uma sociedade virtual e digital e utilizam-se dos instrumentos dessa sociedade para manterem e divulgarem essa cultura analógica, por meio das redes sociais. Como essa participação no espaço coletivo do cineclube é construída e de que maneira os entrevistados se formam nessa relação, é o assunto do próximo item. 


\section{FORMAÇÃO NO CINECLUBE}

Educação, aprendizagem, formação, instrução, estudo, bagagem intelectual, conhecimento, são conceitos que convergem para a noção que engloba a educação de um modo geral. Formação é sinônimo de educação, instrução. Assim, ao investigarmos a dimensão formativa dos cineclubes na trajetória educativa dos jovens universitários, pretendemos descobrir por quais processos de aprendizagem passam esses sujeitos, analisando de que maneira as experiências nas sessões, debates e demais desdobramentos proporcionados pelas atividades nesses espaços agregam mais conhecimento para eles, e em que medida contribuem para sua formação não apenas profissional, mas humana. Por formação humana, compreendemos a formação do sujeito para a vida. Educação e formação seguem uma mesma trilha: a da construção do conhecimento por meio de processos de aprendizagem para determinados fins - isso quando tais conceitos não se confundem num só, significando a mesma coisa. Rodrigues (2001, p. 242) resume seu conceito de educação, levando em consideração uma formação completa do ser:

O ser nascente, não homem, necessita, pois, receber uma formação completa para poder existir junto aos outros homens como um ser igual e completo. Nesse sentido, se diz da Educação que ela é uma totalidade, pois sua ação formativa abarca tanto a dimensão física quanto a intelectual, tanto o crescimento da competência de cada educando para se autogovernar quanto à formação moral que o leve a um adequado relacionamento com os outros homens.

A maioria dos jovens entrevistados compreende a experiência nos cineclubes como relevante para sua formação, pois entendem que não teriam a mesma bagagem que têm caso não tivessem participado do cineclube:

[...] se não fosse o cineclube, o Cinerama, eu acho que eu teria saído com uma bagagem muito menor da faculdade, sabe? Eu acho que se fosse só por uma questão, se fosse seguir só o caminho tradicional, só ir para as aulas e ter perdido esses encontros - que é muito encontro ali que a gente promove - eu acho que eu não teria pensado metade do que eu pensei, e como eu penso hoje em dia, e como a gente quer dar seguimento a isso. (Diego).

Eu acho que o cineclube, ele me deu margem pra isso. Pra eu poder buscar para além do cinema, para eu buscar para além daquela reflexão única ali de estar ali só batendo um papo sobre cinema, sobre talvez outras coisas, mas pra eu querer me 
formar, eu querer coisas pra mim, assim. Até para ampliar esse meu conteúdo, entendeu? (Thiago) (informações verbais).

Thiago explica que o cineclube deu a ele um maior senso crítico para construir argumentos e reflexões sobre diversas situações, sem ficar preso a uma única verdade. Nossa compreensão é de que a partir do que ele vivenciou no cineclube, passou a buscar conhecimento referente a diversos assuntos de seu interesse, inclusive sobre a arte do cinema, em fontes diversas. O cineclube, para ele, funcionou para a abertura de seus horizontes, na busca de outras verdades na ampliação de seus conhecimentos sobre cinema, entre outras coisas.

Os entrevistados ressaltam como relevantes para sua formação, desde aspectos cinematográficos para quem estuda e faz cinema - como o aprimoramento na análise dos filmes, a construção de referências e as dificuldades que permeiam o mercado em que estão inseridos -, até questões que perpassam o relacionamento pessoal, o ouvir o outro e respeitar sua opinião e a ampliação de seus "conteúdos”.

Eu acho que o papel do cineclube, inclusive, de discutir esses filmes depois, acaba trazendo essa linguagem cinematográfica pra mais perto das pessoas. Se você tem oportunidade de conversar sobre o filme, se você não faz cinema, você vai no cineclube, tem oportunidade de conversar sobre o filme que você acabou de ver, com certeza você vai sair dali com muito mais conhecimento sobre cinema. (Clarissa).

A minha vivência no CinePUC com certeza me deu muito mais embasamento pra eu - principalmente nas aulas mais teóricas poder conseguir pegar um livro de um teórico ou de um crítico e conseguir ver que aquele livro. Saber que, sei lá, aquele crítico, aquele teórico, pra escrever aquilo viu milhões de filmes, teve influências e pra eu conseguir entender aquelas milhões de influências eu tenho que ver, eu tenho que, sabe, discutir aquilo ali, eu tenho que correr atrás. [...] Então, eu acho que é assim: com certeza o CinePUC influenciou pra mim, nesse sentido, de criar, gerar um senso crítico. (Thiago).

E eu acho que esse contato foi fundamental e hoje eu sei muito mais o que o cinema pode representar, do que não pode representar, sabe? O que eu vou buscar representar - entendo muito mais esse embate que sempre vai ser cultural, social, ético, sabe? E quando você divulga seu filme para um festival, por exemplo, aquilo ali vai ser julgado não só de maneira criativa, mas o que seu filme representa, quem ele representa, e se ele vai ser aceito ou não, vai passar muito por essas questões. A gente está muito mais atento a isso hoje do que numa relação ingênua com o mundo da indústria cultural. (Diego). 
Por fim, trazemos a consideração de Clarissa sobre a importância do cineclube na sua formação, pois ela consegue resumir o que foi trazido e ressaltado até então sobre o foco desse texto:

[...] o cineclube é importante na formação desse sujeito pensante para além do contexto, digamos, no exemplo que eu dei, do contexto histórico, não é uma coisa que tá ilustrando nada, as pessoas vão lá porque elas querem ver o filme e querem discutir o filme. Isso pra formação não só dos universitários, mas dos sujeitos. (Clarissa).

Esses estudantes que frequentam os cineclubes podem ser considerados “espectadores privilegiados", uma vez que estabelecem uma relação mais de perto com o cinema e tudo o que o envolve. Eles escolhem a forma como consumir seus filmes considerando o que vão ganhar de aprendizado sobre a obra, o cineasta, o mercado cinematográfico, as escolhas artísticas e estéticas do filme, sobre a arte. Os debates feitos em um cineclube podem contribuir com as discussões que serão realizadas nas aulas de cinema que eles frequentam no curso de graduação. O cineclube abre o olhar para se buscar mais, para aprender sobre cinema e tantas outras coisas que serão tratadas no debate. Essa experiência forma curadores, líderes, pessoas desinibidas para falar e atentas a ouvir o outro, num processo coletivo e recíproco de formação. Portanto, existe uma experiência formativa nesses cineclubes que vai além da aprendizagem audiovisual. Duarte (2009, p. 67) confirma o caráter pedagógico da experiência cineclubista, entendida aqui como uma comunidade da qual fazem parte os jovens pesquisados:

Os chamados "espectadores privilegiados" de cinema, frequentemente mais críticos, mais informados e mais politizados do que os demais, formam-se uns aos outros, permanentemente, de geração em geração. Preservam e programam conhecimentos sobre cinema numa rede de parcerias que possibilita troca de saberes e produção/reprodução de valores e crenças compartilhados na comunidade interpretativa da qual participam. Para eles, o cinema atua como elemento aglutinador e como fonte inequívoca de conhecimento, de formação e de informação, configurando-se, assim, como uma prática "eminentemente pedagógica".

\section{CONSIDERAÇÕES FINAIS}

Embora tenham a opção de baixar filmes na internet, os estudantes participantes de nossa pesquisa revelaram gostar de ver filmes em mostras e festivais, pois ali têm a oportunidade de assistir ao filme com som e imagem de alta qualidade e de 
assistirem palestras dos cineastas ou estudiosos daquela obra. Essa escolha de como consumir os filmes nos direcionou para uma questão: o que jovens do século XXI, oriundos de uma cultura digital e virtual fazem num cineclube? Nossa análise sobre esse aspecto nos mostrou o debate - momento de troca, de encontro e de aprendizado - como propulsor dessa escolha.

Concluímos, portanto, que nesse ambiente de trocas coletivas sobre filmes, os estudantes formam-se a si mesmos e uns aos outros, numa relação sem igual de alteridade que também se estende à relação com o filme e com a cultura do cineclube. Essa cultura analógica, que tem quase a mesma idade que o cinema, vivida por outras várias gerações, consegue se estabelecer e se reafirmar dentro dos muros da universidade, num movimento de marginalidade e subversão daqueles que organizam os projetos e que deles participam.

Assim, concluímos que existe uma formação nessa experiência com os cineclubes, os quais atuam como espaços de alteridade, de encontro, de trocas coletivas e significativas sobre os filmes, sobre as técnicas, a linguagem, as escolhas artísticas, construção de roteiros, debates sobre assuntos relevantes e atuais de nossa sociedade. No cineclube os estudantes têm a oportunidade de ver de outro jeito um filme. Pensar de outra maneira um tema que está sendo discutido em sala de aula, ou que está sendo debatido pela/na sociedade. Pelo que conseguimos perceber nas entrevistas cedidas para a pesquisa, os cineclubes instigam o pensar, o buscar e o fazer. E a força dessa prática social vem do debate e do encontro (pessoal) que ele provoca com os colegas, com especialistas em filmes, com diretores, produtores, e consigo mesmos.

\section{Notas explicativas}

\footnotetext{
${ }^{1}$ Este artigo é parte da dissertação de mestrado, intitulada "A dimensão formativa de cineclubes universitários” (FONSECA, 2014), orientada pela Prof $f^{\mathrm{a}}$. Dra . Carmen Irene Correia de Oliveira (Unirio).

${ }^{2}$ Todas as informações sobre os cineclubes aqui apresentados são referentes à época de realização da pesquisa de mestrado, realizada nos anos de 2012 a 2014.

${ }^{3}$ Disponível em: <https://www.facebook.com/cinepucrio?fref=ts>. Acesso em: 6 fev. 2015.

${ }^{4}$ Disponível em: <https://www.facebook.com/cinecinerama?fref=ts>. Acesso em: 6 fev. 2015.

${ }^{5}$ O termo "analógico" é concebido aqui em oposição ao termo "digital" e não no sentido cunhado pelo dicionário.
}

\section{REFERÊNCIAS}

AMANCIO, T. Prefácio. In: MATELA, R. C. Cineclubismo: memórias dos anos de chumbo. Rio de Janeiro: Luminária Academia, 2008.

BAECQUE, A. Cinefilia. São Paulo: Cosac Naify, 2010. 
DUARTE, R.; ALEGRIA, J. Formação estética audiovisual: um outro olhar para o cinema a partir da educação. Educação e Realidade: Dossiê Cinema e Educação, Porto Alegre, v. 33, n. 1, p. 59-80, jan./jun. 2008.

DUARTE, R. Cinema e educação. 3. ed. Belo Horizonte: Autêntica, 2009.

FONSECA, M. J. S. A dimensão formativa de cineclubes universitários. 2014. Dissertação (Mestrado em Educação) - Universidade Federal do Estado do Rio de Janeiro, Rio de Janeiro, 2014. Disponível em: <https://docs.google.com/file/d/0B-sE2Ar37CoNUkI0Z0R6OGtJekE/edit?pref=2\&pli=1>. Acesso em: 20 jan. 2016.

FRESQUET, A. Cinema e educação: reflexões e experiências com professores e estudantes de educação básica, dentro e "fora" da escola. Belo Horizonte: Autêntica, 2013. (Coleção Alteridade e Criação, 2).

GARCÍA CANCLINI, N. Consumidores e cidadãos. Rio de Janeiro: Ed. UFRJ, 2010.

GUSMÃO, M. C. S. O desenvolvimento do cinema: algumas considerações sobre o papel dos cineclubes para a formação cultural. In: ENCONTRO DE ESTUDOS MULTIDISCIPLINARES EM CULTURA, 4., Salvador, 2008. Anais eletrônicos... Salvador, 2008. Disponível em: <http://www.cult.ufba.br/enecult2008/14469.pdf >. Acesso em: 12 jun. 2011.

LARROSA BONDÍA, J. Notas sobre a experiência e o saber de experiência. Tradução de João Wanderley Geraldi. Revista Brasileira de Educação, Rio de Janeiro: Autores Associados, n. 19, p. 20-28, abr. 2002.

MACEDO, F. Cineclube e autoformação do público. In: MACEDO, F.; ALVES, Giovanni (Org.). Cineclube, cinema e educação. Londrina: Praxis 6, 2010. (Série Tela Crítica).

MATELA, R. C. Cineclubismo: memórias dos anos de chumbo. Rio de Janeiro: Luminária Academia, 2008.

RODRIGUES, N. Educação: da formação humana à construção do sujeito ético. Educação e Sociedade, ano 22, n. 76, p. 232-257, out. 2001.

Recebido em 12 de agosto de 2015 Aceito em 01 de fevereiro 2016

Endereço para correspondência: Boulevard, 28 de Setembro, Vila Isabel, 20.551031 Rio de Janeiro, Rio de Janeiro, Brasil; mirnajuliana@gmail.com 
